\author{
Asian Journal of \\ Medical and Biological Research \\ ISSN 2411-4472 (Print) 2412-5571 (Online) \\ www.ebupress.com/journal/ajmbr
}

\title{
Article \\ Isolation, molecular identification and antibiotic susceptibility profile of Aeromonas hydrophila from cultured indigenous Koi (Anabus testudineus) of Bangladesh
}

Shuvho Chakra Borty ${ }^{1,3,4,5^{*}}$, Fabaya Rahman ${ }^{2}$, A.K.M. Ali Reza ${ }^{3,4,5}$, Mst. Sharifa Khatun ${ }^{3,4,5}$, Md. Luthful Kabir ${ }^{1}$, Muhammed Hafizur Rahman ${ }^{3,4,5}$ and Md. Shirajum Monir ${ }^{6}$

${ }^{1}$ Department of Microbiology and Hygiene, Bangladesh Agricultural University, Mymensingh, Bangladesh

${ }^{2}$ Department of Pathology, Gonoshasthaya Samaj Vittik Medical College, Gono Bishwabidyalay, Savar, Dhaka, Bangladesh

${ }^{3}$ Department of Quality Assurance, Igloo Ice-Cream and Milk Unit, Kadamtali, Shampur, Dhaka-1204, Bangladesh

${ }^{4}$ Department of Quality Assurance, Frozen Food Unit-Igloo Foods Ltd., Kadamtali, Shampur, Dhaka-1204, Bangladesh

${ }^{5}$ Department of Quality Control, Igloo Dairy Ltd., Kadamtali, Shampur, Dhaka-1204, Bangladesh

${ }^{6}$ Freshwater Station, Bangladesh Fisheries Research Institute, Mymensingh-2201, Bangladesh

*Corresponding author: Shuvho Chakra Borty, Department of Microbiology and Hygiene, Bangladesh Agricultural University, Mymensingh-2202, Bangladesh and Department of Quality Assurance, Frozen Food Unit-Igloo Foods Ltd., Kadamtali, Shampur, Dhaka-1204, Bangladesh. Mobile: +8801710500560; E-mail: shuvho.micro@gmail.com

Received: 07 June 2016/Accepted: 23 June 2016/ Published: 30 June 2016

\begin{abstract}
Fish play a crucial role in the Bangladeshi diet, providing more than $60 \%$ of animal source food, representing a crucial source of micro-nutrients and possessing an extremely strong cultural attachment. In this study isolation and identification of Aeromionas hydrophila was done by studying cultural properties, Gram's staining and biochemical properties of isolates of diseased indigenous Koi fish (Anabas testudineus) of different upazillas of Mymensingh district. Antibiogram profile of the isolated bacteria was studied by using wide range of commercially available antibiotics. Quantitative study of bacteria isolated from diseased indigenous Koi fish showed variation of number in different organ. Total bacterial load was found to be $1.90 \times 105,1.19 \times 105,3.21$ $\times 105,2.18 \times 106$ and $3.14 \times 105 \mathrm{cfu} / \mathrm{g}$ in lesions; $2.52 \times 107,2.34 \times 108,5.41 \times 108,2.54 \times 109$ and $5.21 \times$ $109 \mathrm{cfu} / \mathrm{g}$ in liver; $2.54 \times 108,2.41 \times 108,1.90 \times 107,3.65 \times 107$ and $3.45 \times 108 \mathrm{cfu} / \mathrm{g}$ in spleen; $3.51 \times 107$, $5.28 \times 107,3.14 \times 106,1.85 \times 107$ and $4.52 \times 107 \mathrm{cfu} / \mathrm{g}$ in kidney in diseased Koi of Mymensingh sadar, Muktagacha, Tarakanda, Gouripur and Fulpur upazillas, respectively under Mymensingh districts. Aeromonas hydrophila was initially identified by their specific morphological, physiological and biochemical characteristics. Then molecular detection of A. hydrophila was done by PCR. PCR products of desired $760 \mathrm{bp}$ were obtained for A. hydrophila. The results of the antibiotic sensitivity test is exhibited that most of the bacterial samples were sensitive against ciprofloxacin (92\%) and levofloxacin (84\%), intermediate resistant against gentamicin (40\%) and resistant against novobiocin (84\%), ampicillin (100\%) and penicillin (92\%).
\end{abstract}

Keywords: aquaculture; climbing perch; bacterial infection; Koi; bacterial load; Aeromonas

\section{Introduction}

The Climbing Perch fish Anabas testudineus (Bloch, 1792) is one of the important small indigenous species (SIS), fresh water fish of Bangladesh, which is locally known as Koi in different places of Bangladesh. SIS is generally considered to be those fishes which grow to a maximum length of about $25 \mathrm{~cm}$ (Felts et al., 1996 and 
Hossain et al., 1991). This fish is native in Southeast Asian region, often found in fresh water sources of east India and south China (Chakraborty et al., 2014). It is commonly found in open water (streams, lakes, floodplain and beels), paddy fields and swamps of Bangladesh and its preferred habitats are heavily-vegetated, stagnant waters. Total length is recorded $176 \mathrm{~mm}$ (Rahman et al., 1989). The fish is very popular for its delicious taste and flavour. This species considered as a valuable item of diet for sick and convalescent (Kohonoor et al., 2012). According to Saha et al., 1971, the fish contain high values of physiologically available iron and copper essentially needed for hemoglobin synthesis. This fish was abundantly available in our open water system but due to over exploitation and various ecological changes in its natural habitat; this native species is declining. Indiscriminate destructive practices have caused havoc to aquatic biodiversity (Hussain et al., 2001). International Union of Conservation of Nature (IUCN) enlisted A. testudineus as not threatened perch fish in Bangladesh. But due to rough and unplanned water management policy for irrigation, over exploitation, illegal practice of capture fisheries and various ecological changes in its natural habitat; this native species is threatened now (Chakraborty et al., 2010). A decade ago, SIS was cultured in the pond as an additional crop while various large carp species were cultured as cash crop. Nevertheless, production systems are continuously changing (Rahman et al., 2006). Nowadays, fish farmers culture SIS as a main cash crop (Jannat et al., 2012) In Bangladesh, a wide variety of SIS is available, among these Climbing Perch Koi Anabas testudineus (Bloch 1792), Taki Channa punctata (Bloch 1793), Veda Nandus nandus (Hamilton 1822), Pabda Ompok pabda (Hamilton 1822), Tengra Mystus vittatus (Bloch 1794), Mola Amblypharyngodon mola (Hamilton 1822), Puti Puntius sophore, Shing Heteropneustes fossilis (Bloch 1794), Magur Clarias batrachus (Linnaeus 1758), Chapila Gudusia chapra (Hamilton 1822), Chela Salmophasia bacaila (Hamilton 1822), Chanda Chanda nama (Hamilton 1822) are regarded as major SIS crop (Jannat et al., 2012). Nowadays, among SIS climbing perch is the most popular aquaculture species and its aquaculture production is increasing very rapidly (Belton et al., 2011). Considering the importance of this species in nutritional, economical and biodiversity point of view, this species (A. testudineus) is being cultured in large scale across the country (Mondal et al., 2010).

The current trend in aquaculture development is towards increased intensification and commercialization of aquatic production. Like other farming sectors, the likelihood of major disease problems increases as aquaculture activities intensify and expand (Hasan et al., 2013). Disease is considered as a primary constraint to the culture of many aquatic species, impeding both economic and social development in many countries (Subasinghe et al., 2001). A number of diseases like epizootic ulcerative syndrome, skin erosion, gill damage, tail and fin rot are common in farmed Climbing Perch of Bangladesh (Faruk et al., 2004). In pond aquaculture system, high stocking density and irregularly feed supply is very prone to disease outbreak. Most pond fish farmers of Climbing Perch do not have a good understanding of health and disease issues in their system (Hasan et al., 2013). Many diseases of this hardy fish are secondary to environmental insult, and can be prevented through proper management by manipulating the ecosystem and the administration of selective antibiotics. However, there is hardly such scientific information available from which rural pond aqua-farmers could be benefited.

The objectives of the present study were therefore isolation, identification and molecular detection of actual disease causing agent which is responsible for mass mortality of cultured indigenous Koi (A. testudineus) of Mymensingh district of Bangladesh.

\section{Materials and Methods}

\subsection{Selection of fish farms and study area}

Different Climbing Perch, Koi (A. testudineus) farms of Muktagacha, Tarakanda, Gouripur, Fulpur, Sadar upazillas under Mymensingh district located at $24^{\circ} 38^{\prime} 3^{\prime \prime} \mathrm{N} 90^{\circ} 16^{\prime} 4^{\prime \prime} \mathrm{E}$ of Bangladesh were selected to collect infected Koi fish samples for isolation, identification and molecular detection of actual pethogenic agent and evaluate their antimicrobial resistance patterns. The study was conducted from April, 2014 to October, 2015 to collect the samples in various seasones round the year.

\subsection{Fish sample collection}

Samples were collected from a total of 20 afflicted Koi farms depending on the availability of diseased fish from the study area in which Koi (A. testudineus) were suffering from tail and fin rot, reddish hemorrhagic external lesions and some asymptomatic causes. Moribund fishes were collected in clean sterile boxes containing ice packs and then transported to Fish Disease and Health Management Laboratory of Bangladesh Fisheries Research Institute, Mymensingh. The clinical signs and postmortem findings were recorded according to Rashid et al., 2008 and Ahmed et al., 2009. 
2.3. Bacteriological examination

Specimens from diseased Koi's skin, gill, liver and kidney were inoculated on Trypticase Soya Agar (TSA) plates and then incubated at $30^{\circ} \mathrm{C}$ for $24 \mathrm{hrs}$. The isolated bacteria were identified according to their biochemical characteristics (Sabur et al., 2006, Narejo et al., 2005).

\subsection{Clinical observation}

Collected fish were examined to observe their external lesion, injury or any other abnormalities and were recorded properly.

\subsection{Total viable count of bacteria}

At first each Koi fish was examined for its clinical sign of disease and disorders. A drop of blood was dissolved on TSA plate for colony counting. The fish was dissected immediately after clinical examination. The portions of skin, gill, kidney, liver and intestine were removed, weighed on an electric balance and kept in a sterilized pastel mortar for crushing. Each organ was crushed with physiological saline in the ratio of $0.1 \mathrm{~g}$ of organ: 0.9 $\mathrm{ml}$ of PBS to make stock solution. Eight decimal dilutions were prepared by transferring $0.1 \mathrm{ml}$ from the earlier test tube to the next. These eight tubes were designated as $10^{-1}, 10^{-2}, 10^{-3}, 10^{-4}, 10^{-5}, 10^{-6}, 10^{-7}$ and $10^{-8}$. Two samples of $0.1 \mathrm{ml}$ from $10^{-2}$ and $10^{-3}$ in case of liver and kidney; $10^{-3}$ and $10^{-4}$ in case of intestine were transferred to Aeromonas isolation medium (AIM) to get only the colonies of Aeromonas spp.

Total bacterial load of each organ was calculated using the following formula used by Rashid et al. (2008). Avarage number of colonies on plates

Total bacterial load $=$ Dillution factor $\times$ Volume plated

\subsection{Identification of Aeromonas spp.}

Identification of Aeromonas spp. was done based on detailed morphological, physiological and biochemical characterization of the isolates. At first, the bacteria were sub-cultured onto TSA plates to obtain fresh 24 hours culture. They were then streaked onto the selective Aeromonas isolation medium (AIM) for preliminary identification of the genus Aeromonas and discarding the others. Colonies grown on the selective medium were sub-cultured again onto TSA plates and subjected to biochemical tests using commercially available media after autoclaving at $121^{\circ} \mathrm{C}$ for 15 minutes.

\subsection{Motility test}

For motility test young and actively growing culture of the bacteria were collected from $24 \mathrm{~h}$ culture at $30^{\circ} \mathrm{C}$. A single colony was mixed with $3 \mathrm{ml}$ of PBS. A drop of the suspension was taken on clean glass slide, covered with cover slip and placed under a luminous microscope. Bacterial motility was observed in a LCD monitor screan, adjusted with the microscope (OLYMPUS, Model CHS, Japan).

\subsection{Physiological characterization}

Physiological characters were studied by observing the growth of each isolate at temperature of $4{ }^{\circ} \mathrm{C}, 37^{\circ} \mathrm{C}$ and $40^{\circ} \mathrm{C}$. Growth of each isolate was observed in different concentrations of $\mathrm{NaCl}$ as $0 \%, 1 \%, 2 \%, 3 \%, 3.5 \%$ and $4 \%$.

\subsection{Biochemical characterization}

Several biochemical tests were performed to evaluate the biochemical behavior of isolated bacteria. Biochemical tests are oxidase, catalase, oxidative-fermentative test, 0129 test, esculin hydrolysis test, acid and gas production from sugars: glucose, lactose, sucrose, manitol; methyl-red (MR) test, Voges-Proskauer (VP) test, indole and $\mathrm{H} 2 \mathrm{~S}$ production, decarboxylase test, citrate utilization test.

\subsection{Molecular dectection of Aeromonas hydrophila}

The genomic DNA was isolated as per the protocol described by Swaminathan et al. (2004). A single colony was inoculated in $10 \mathrm{ml}$ of Nutrient broth (NB) and grown at $29^{\circ} \mathrm{C}$ overnight. Culture was centrifuged at 5000 $\mathrm{rpm}$ for 10 minutes. Four hundred microlitre of solution I (50mM Tris.HCl pH-8.0, 50mM EDTA pH-8.0, 25\% sucrose, $1 \mathrm{mg}$ lysozyme), was added to the washed cell pellet and gently mixed and incubated at $37^{\circ} \mathrm{C}$ for 15 minutes. Thereafter $400 \mathrm{ml}$ of solution II $(10 \mathrm{mM}$ Tris. $\mathrm{HCl} \mathrm{pH} 8.0,5 \mathrm{mM}$ EDTA pH-8.0, $1 \%$ SDS, $40 \mu \mathrm{g}$ Proteinase K) was added to the cells and incubated at $55^{\circ} \mathrm{C}$ for three hours. The suspension was centrifuged at 
$6000 \mathrm{rpm}$ for 10 minutes. The aqueous layer from the top was removed carefully to avoid any protein debris and transferred to a fresh microfuge tube. Double amount of chilled ethanol was added to aqueous phase so as to precipitate the DNA. The DNA was pellted by centrifugation at $12000 \mathrm{rpm}$ for 10 minutes. The pellet, washed with 70\% ethanol was dried and dissolved in $100 \mu \mathrm{l}$ of TE buffer (pH 7.6). Primer used for the amplification of DNA as shown in Table 1. PCR was done as per the method described previously by Narjeo et al. (2005). Amplification was performed with a DNA thermal cycler (Mastercyclear, Eppendorf, Humburg, Germany) with some modifications as follows: The reaction mixture consisted of $1 \mu \mathrm{l}$ of Taq polymerase (1 unit), $5 \mu \mathrm{l}$ of $10 \mathrm{X}$ PCR amplification buffer (100 mM Tris-Hcl, $25 \mathrm{mM} \mathrm{MgCl} 2,500 \mathrm{mM} \mathrm{KCl}, \mathrm{pH}-8.3), 3 \mu 1$ of deoxynucleoside triphosphate $(100 \mu \mathrm{M}), 0.5 \mu 1$ of each primer $(100$ pmoles $)$ and double distilled water upto a final volume of 50 $\mu 1$. A total of 40 PCR cycles were run under the following conditions: Initial denaturation at $94^{\circ} \mathrm{C}$ for 4 minutes, denaturation at $94^{\circ} \mathrm{C}$ for 1 minute, primer annealing at $65^{\circ} \mathrm{C}$ for 1 minute, DNA extension at $72^{\circ} \mathrm{C}$ for 1.5 minutes and final extension at $72^{\circ} \mathrm{C}$ for 5 minutes.

Table 1. List of primers used for Aeromonas hydrophila genome detection.

\begin{tabular}{llll}
\hline Primers & Sequences $\left(\mathbf{5}^{\prime}-\mathbf{3}^{\prime}\right)$ & Amplicon size (bp) & Reference \\
\hline Forward Primer & 5'-AACCTGGTTCCGCTCAAGCCGTTG- 3' $^{\prime}$ & \multirow{2}{*}{760} & \multirow{2}{*}{ Nerjeo et al., 2005 } \\
Reverse Primer & 5'-TTGCCTCGCCTCGGCCCAGCAGCT- 3' $^{\prime}$ & & \\
\hline
\end{tabular}

\subsection{Antibiogram profile of Aeromonas hydrophila}

All bacterial isolates were tested for their sensitivity to ten commercially available antibiotics by the disc diffusion method. The antibiotics, their codes and concentrations were as follows: ampicillin (10 $\mu \mathrm{g})$, ciprofloxacin $(5 \mu \mathrm{g})$, gentamicin $(10 \mu \mathrm{g})$, oxytetracycline $(10 \mu \mathrm{g})$, penicillin $(10 \mu \mathrm{g})$, tetracycline $(30 \mu \mathrm{g})$, levofloxacin $(5 \mu \mathrm{g})$, azithromycin $(10 \mu \mathrm{g})$, chlortetracycline $(25 \mu \mathrm{g})$, novobiocin $(5 \mu \mathrm{g})$. Tested bacterial strains were classified into three categories: sensitive, intermediate, and resistant and depending on the diameters of inhibition zones and standards supplied by Himedia Laboratories and comparing with other related references (Table 2). All tests were carried out in Fish Diseases and Health Management Laboratory of Bangladesh Fisheries Research Institute (BFRI), Mymensingh.

Table 2. Interpretation standards for disc diffusion susceptibility testing for Aeromonas hydrophila (CLSI 2012).

\begin{tabular}{llllll}
\hline Sl. No. & Name of Antimicrobial agent & Disc concentration & & \multicolumn{2}{c}{$\begin{array}{c}\text { Interpretation of results } \\
\text { (zone in diameter in mm) }\end{array}$} \\
\cline { 3 - 5 } & & & I & S \\
\hline 1 & Ciprofloxacin & $5 \mu \mathrm{g}$ & $\geq 16$ & $12-15$ & $\leq 17$ \\
2 & Levofloxacin & $5 \mu \mathrm{g}$ & $\geq 22$ & $17-21$ & $\leq 23$ \\
3 & Gentamicin & $10 \mu \mathrm{g}$ & $\geq 14$ & $10-13$ & $\leq 15$ \\
4 & Azithromycin & $15 \mu \mathrm{g}$ & $\geq 16$ & $11-15$ & $\leq 17$ \\
5 & Tetracycline & $30 \mu \mathrm{g}$ & $\geq 14$ & $09-13$ & $\leq 15$ \\
6 & Oxytetracycline & $10 \mu \mathrm{g}$ & $\geq 15$ & $11-14$ & $\leq 16$ \\
7 & Chlortetracycline & $25 \mu \mathrm{g}$ & $\geq 16$ & $13-15$ & $\leq 17$ \\
8 & Novobiocin & $5 \mu \mathrm{g}$ & $\geq 17$ & $14-17$ & $\leq 18$ \\
9 & Ampicillin & $10 \mu \mathrm{g}$ & $\geq 22$ & $16-21$ & $\leq 23$ \\
10 & Penicillin & $10 \mu \mathrm{g}$ & $\geq 14$ & $10-13$ & $\leq 15$ \\
\hline
\end{tabular}

$\mathrm{Sl}=$ Serial, No. = Number, $\mu \mathrm{g}=$ Microgram, $\mathrm{mm}=$ Millimeter, $\mathrm{S}=$ Susceptible, $\mathrm{I}=$ intermediately resistant, $\mathrm{R}=\mathrm{Resistant}$, $\geq=$ Greater than or equal to, $\leq=$ Less than or equal to.

\section{Results}

\subsection{Clinical and post mortem findings}

The clinical examination of diseased Koi (A. testudineus) exhibited: loss of equilibrium, slight lesion on body, body and tail erosion, hemorrhage in base of fin and edge of head, move with whirling and heavy mortalities of fish occur shortly after the advent of lesions. Congestion and enlargement in internal organs were appeared in postmortem examination. 
3.2. Bacterial load in skin lesions, liver, spleen and kidney

Bacterial load in skin lesions, liver, spleen and kidney of infected Koi (A. testudineus) are calculated and then observed to have a variation. Total bacterial load was found to be $1.90 \times 10^{5}, 1.19 \times 10^{5}, 3.21 \times 10^{5}, 2.18 \times 10^{6}$ and $3.14 \times 10^{5} \mathrm{cfu} / \mathrm{g}$ in lesions; $2.52 \times 10^{7}, 2.34 \times 10^{8}, 5.41 \times 10^{8}, 2.54 \times 10^{9}$ and $5.21 \times 10^{9} \mathrm{cfu} / \mathrm{g}$ in liver; 2.54 $\times 10^{8}, 2.41 \times 10^{8}, 1.90 \times 10^{7}, 3.65 \times 10^{7}$ and $3.45 \times 10^{8} \mathrm{cfu} / \mathrm{g}$ in spleen; $3.51 \times 10^{7}, 5.28 \times 10^{7}, 3.14 \times 10^{6}, 1.85$ $\times 10^{7}$ and $4.52 \times 10^{7} \mathrm{cfu} / \mathrm{g}$ in kidney in diseased Koi of Mymensingh sadar, Muktagacha, Tarakanda, Gouripur and Fulpur upazillas, respectively under Mymensingh district.

\subsection{Morphological, physiological and biochemical test results}

The isolated Aeromonas hydrophila from diseased Koi was finally identified by their specific morphological, physiological and biochemical characteristics. They were Gram negative, rod shaped, motile bacteria, positive for oxidase and catalase test. They fermented glucose and were resistant to vibriostatic agent 0129 test. The results of morphological, physiological and biochemical tests are presented in bellow Table 3 ,

Table 3. Results of biochemical characteristic of isolated bacteria.

\begin{tabular}{|c|c|c|c|}
\hline Characters & $\begin{array}{l}\text { Characterization by } \\
\text { Mostafa et al. (2008) }\end{array}$ & $\begin{array}{l}\text { Characterization by } \\
\text { Sabur (2006) }\end{array}$ & Present result \\
\hline Gram's stain & - & - & - \\
\hline Shape & Rod & Rod & Rod \\
\hline Motility & + & + & + \\
\hline 0129 & ND & ND & - \\
\hline Oxidase & + & + & + \\
\hline Catalase & + & + & \\
\hline OF test & $\mathrm{F}$ & $\mathrm{F}$ & $\mathrm{F}$ \\
\hline Glucose & + & + & + \\
\hline Lactose & + & + & + \\
\hline Sucrose & + & + & + \\
\hline Maltose & + & + & + \\
\hline Manitol & + & + & - \\
\hline Inositol & - & - & - \\
\hline Sorbitol & - & - & - \\
\hline Rhamnose & - & - & - \\
\hline Esculin hydrolysis & + & + & + \\
\hline Methyl-red test & - & - & - \\
\hline Voges-Proskaur & + & + & + \\
\hline Indole & + & + & + \\
\hline $\mathrm{H} 2 \mathrm{~S}$ production & + & + & - \\
\hline Arginine decomposition & + & + & + \\
\hline Lysine decarboxilation & - & - & - \\
\hline Ornithine decarboxilation & - & - & - \\
\hline Citrate utilization & + & + & + \\
\hline TSI & ND & ND & $\begin{array}{l}\text { ' } \mathrm{K} \text { ' in slants but } \\
\text { ' } A \text { ' in butt }\end{array}$ \\
\hline Growth at: & - & - & - \\
\hline $5^{\circ} \mathrm{C}$ & + & + & + \\
\hline $37^{\circ} \mathrm{C}$ & + & + & + \\
\hline $40^{\circ} \mathrm{C}$ & - & - & - \\
\hline
\end{tabular}

+: Negative; -: Positive; F: Fermentative; K: Alkaline; A: Acid, ND: Not done

\subsection{Molecular detection of Aeromonas hydrophila by PCR}

PCR products of desired size $760 \mathrm{bp}$ were obtained in reaction mixture containing genomic DNA of the targeted organisms, A. hydrophila (Figure 1). No product was detected in control (Figure 1). 


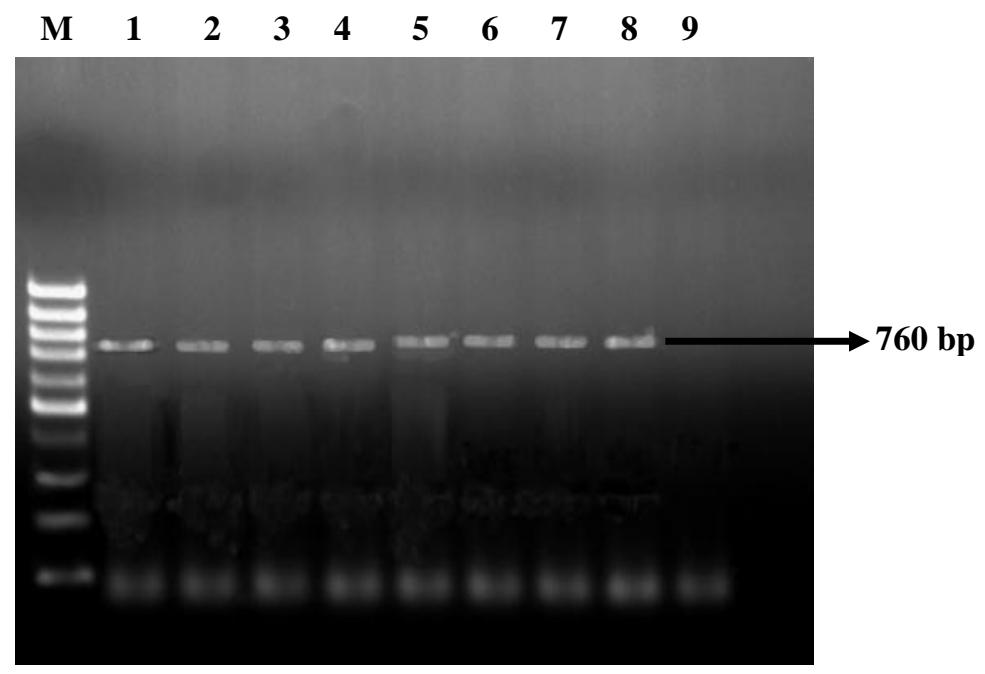

Figure 1. Agarose gel electrophoresis of PCR amplification generated by Aeromonas hydrophila. Lanes: (M) 100 bp DNA marker; (1-8) positive samples from field; (9) negative control.

\subsection{Antibiotic sensitivity test}

The isolated Aeromonas hydrophila were tested against ten commercially available antibiotics and the results of their sensitivity are presented in Table 4 . Most of the bacterial samples were sensitive against ciprofloxacin (92\%) and levofloxacin (84\%), intermediate against gentamicin (40\%) and resistant against novobiocin (84\%), ampicillin (100\%) and penicillin (92).

Table 4. Antibiogram profile of isolated Aeromonas hydrophila $(\mathrm{n}=25)$.

\begin{tabular}{llll}
\hline Antibiotics & \multicolumn{3}{c}{ No (\%) } \\
\cline { 2 - 4 } & Sensitive & Intermediate & Resistant \\
\hline Ciprofloxacin $(5 \mu \mathrm{g})$ & $23(92)$ & $2(8)$ & $0(0)$ \\
Levofloxacin $(5 \mu \mathrm{g})$ & $21(84)$ & $4(16)$ & $0(0)$ \\
Gentamicin $(10 \mu \mathrm{g})$ & $15(60)$ & $10(40)$ & $0(0)$ \\
Azithromycin $(15 \mu \mathrm{g})$ & $12(48)$ & $8(32)$ & $3(12)$ \\
Tetracycline $(30 \mu \mathrm{g})$ & $4(16)$ & $12(48)$ & $9(36)$ \\
Oxytetracycline $(10 \mu \mathrm{g})$ & $1(4)$ & $10(40)$ & $14(56)$ \\
Chlortetracycline $(25 \mu \mathrm{g})$ & $3(12)$ & $13(52)$ & $9(36)$ \\
Novobiocin $(5 \mu \mathrm{g})$ & 0 & $4(16)$ & $21(84)$ \\
Ampicillin $(10 \mu \mathrm{g})$ & 0 & 0 & $25(100)$ \\
Penicillin & 0 & $2(8)$ & $23(92)$ \\
\hline
\end{tabular}

\section{Discussion}

The clinical and post mortem findings of the diseased Koi fishes in this study is quite in consonance with those that reported by Ahmed et al., 2009 and Chandra et al., 1994. The Aeromonas hydrophila bacteria was isolated from diseased fish from different locations such as Mymensingh sadar, Muktagacha, Tarakanda, Gouripur and Fulpur upazillas. Total bacterial load was found to be $1.90 \times 10^{5}, 1.19 \times 10^{5}, 3.21 \times 10^{5}, 2.18 \times 10^{6}$ and $3.14 \times$ $10^{5} \mathrm{cfu} / \mathrm{g}$ in lesions; $2.52 \times 10^{7}, 2.34 \times 10^{8}, 5.41 \times 10^{8}, 2.54 \times 10^{9}$ and $5.21 \times 10^{9} \mathrm{cfu} / \mathrm{g}$ in liver; $2.54 \times 10^{8}, 2.41$ $\times 10^{8}, 1.90 \times 10^{7}, 3.65 \times 10^{7}$ and $3.45 \times 10^{8} \mathrm{cfu} / \mathrm{g}$ in spleen; $3.51 \times 10^{7}, 5.28 \times 10^{7}, 3.14 \times 10^{6}, 1.85 \times 10^{7}$ and $4.52 \times 10^{7} \mathrm{cfu} / \mathrm{g}$ in kidney of diseased shing fish of different upazillas of Mymensingh district consecutively. Rashid et al. 2008 and Hasan et al., 2007 found $1.67 \times 10^{4}$ to $6.4 \times 10^{8} \mathrm{CFU} / \mathrm{g}, 1.71 \times 10^{3}$ to $1.18 \times 10^{9} \mathrm{CFU} / \mathrm{g}$ and $1.47 \times 10^{4}$ to $3.70 \times 10^{8} \mathrm{CFU} / \mathrm{g}$ of bacteria in liver, kidney and intestine of naturally infected Thai pangas respectively, those findings is partially similar with our study. Allison (2007) isolated A. hydrophila from Thai pangus, the bacterial load was found $2.6 \times 10^{6}$ to $3.6 \times 10^{7} \mathrm{CFU} / \mathrm{g}$ in liver, $4.8 \times 10^{6}$ to $7.2 \times 10^{7} \mathrm{CFU} / \mathrm{g}$ in intestine and $2.4 \times 10^{3}$ to $3.70 \times 10^{6} \mathrm{CFU} / \mathrm{g}$ in kidney, this is also in consonance with our study. Rahman and Chowdhury (1996) isolated A. hydrophila from kidney of carp fishes, total load of bacteria varied in the kidney of different sampled fishes were $2.6 \times 10^{5}$ to $1.7 \times 10^{6} \mathrm{CFU} / \mathrm{g}$. Here the variations might be caused by different factors like temperature, $\mathrm{p}^{\mathrm{H}}$, chemical and gaseous composition etc. that influences the disease incidence. Ahmed (2009) was found total bacterial load to be $2.45 \times 10^{3}$ (koi) in blood and $8.70 \times 10^{6}$ (koi) CFU/g in 
intestine these findings are almost similar to our study. The morphological and physiological characteristics of A. hydrophilla observed in this study was partially in consonance with those that found by Mostafa et al., 2008 and Islam et al., 2008. Hussain et al. 2014 also found focal necrosis haemorrrhages in the liver tissue, atrophy of the renal tubule in kidney and villi missing in intestine from the naturally infected shing fish by Aeromonas hydrophila in a mixed infection with the Aphanomyces invadans elicited EUS disease.

The biochemical characteristics of the isolated A. hydrophilla in this study are quite in consonance with those that reported by Mostafa et al., 2008 and Sabur et al., 2006. For the molecular detection of the bacterial causative agent of Koi fish diseases PCR was done by using gene specific primer according to Hasan et al., 2007. The antibiogram profile of different antibiotics against Aeromonas hydrophila was found similar to those that previously reported by Hussain et al., 2014, Sobur et al., 2006, and Mostafa et al., 2008. The result of this study will be beneficial for the fish farmers who are regularly culturing Climbing Perch, Koi for diagnosing and controlling diseases by the administration of specific antibiotics. Future research scopes are the pathogencity test of the bacteria for homologous susceptible fishes, identification of pathogenicity island in chromosome, production of antibiotics against Aeromonas hydrophila, serotyping of all A. hydrophila isolates.

\section{Conclusions}

The present study was conducted to identify the Aeromonas hydrophila from Climbing Perch, Koi (A. testudineus). In addition, clinical and bacteriological studies were carried out to examine disease status of cultured Shing fish of Mymensingh district. According to the farmer's opinion, the disease occurring seasons were early and late winter and frequency of disease occurrence was 1 to 2 times in a year. Koi was found to have high mortality rate. About $80-90 \%$ mortality occurs due to diseases. Massive pathological changes were found in different organs of diseased sample. Application of lime and salt in pond were the most common treatment followed by the use of antibiotics, potassium permanganate and copper sulphate. This study also identified fish health management problems which included poor understanding on fish disease and health management, lack of suitable therapeutics and their appropriate uses and lack of assistance regarding disease treatment. Therefore, more precautionary measures need to be taken at the onset of winter season to prevent diseases. So, attention should be drawn to maintain appropriate ambient for rearing Koi fish to avoid common diseases.

\section{Acknowledgements}

The authors are expressing cordial thanks and gratitude to all the stuffs of the Department of Microbiology and Hygiene of Bangladesh Agricultural University and Bangladesh Fisheries Research Institute, Mymensingh, Bangladesh to fulfill the experimental work successfully and also for providing continuous support and sincere cooperation.

\section{Conflict of interest}

None to declear.

\section{References}

Ahmed MB, 2009. Isolation and Identification of Aeromonas hydrophila from Carps, Perch and Catfishes, MS Thesis, Department of Aquaculture, Bangladesh Agricultural University, Mymensingh, Bangladesh.

Allison EH, NL Andrew and J Oliver, 2007. Enhancing resilience of inland fisheries and aquaculture systems to climate change. J. Semi-Arid Trop. Agri. Res., 4: 1-25.

Banu ANH and MH Khan, 2000. Annual Report, Bangladesh Fisheries Research Institute, 69-73 pp.

Chakraborty BK and SM Haque, 2014. Growth, yields and returnes to Koi, Anabas testudineus (Bloch, 1792) under semi intensive agriculture system using different sheed types in Bangladesh. J. Fis. And Livest. Prod., 2: $113-119$.

Chandra KJ, 1994. Infections, concurrent infect ions and fecundi ty of Procamallanus, parasitic to the fish Heteropneustes fossilis. Envir. and Eco., 12: 679-684.

Chowdhury MBR, 1998. Involvement of aeromonad and pseudomonads in diseases of farmed fish in Bangladesh. Fish Path., 33: 247-254.

Chowdhury MBR, 1997. Bacterial involvement in fish disease in Bangladesh. Presented at the International Symposium on Disease in Marine Aquaculture, Hiroshima, Japan.

Chowdhury MBR, 1993. Research priorities for microbial fish disease and its control in Bangladesh. In: Proceeding of the Workshop on Research Priorities of Bangladesh for fish health, disease prevention and pathology (ed. A. Tollervey), 8-11 pp. 
Dehadrai PV, KM Yusuf and RK Das, 1985. Package and practices for increasing production of air breathing fishes. In Aquaculture Extension Manual, New Series, Information and Extension Division of CIFRI. Indian Council of Agriculture Research pp. 1-14.

DoF 2013. Department of Fisheries, National Fish Week 2013 Compendium. Ministry of Fisheries and Livestock, Bangladesh.

Dutta HM, A Nash, S Adhikari, PK Roy, NK Singh and JSD Munshi, 1994. Sublethalmalathion induced changes in the ovary of an air-breathing fish, Heteropneustes fossilis: a histological study. Hydrobiology, 294: $215-218$.

Dwivedi H, 2000. Long term effects of acenaphthene (PAH) on the liver of catfish Heteropneustes fossilis. J. Ecotox. and Envir. Moni., 10: 47-52.

Food and Agricultural Organization, 2013. Fisheries and Aquaculture Department, Global Aquaculture.

Hasan MA, 2007. Pathogenicity of Aeromonas hydrophila in EUS like disease affected Heteropneustes fossilis. MS Thesis. Department of Aquaculture, Bangladesh Agricultural University.

Hossain MA, ANH Banu and MH Khan, 1994. Prevalence of ecto-parasite in carp nursery operation of greater Mymensingh. Prog. Agri., 5: 39-44.

Hussain MG, 2014. Global opportunity for fisheries and aquaculture in Bangladesh. Paper presented in the 2nd International Exhibition and Seminar Dairy, Aqua and Pet Animals-2014, 27 February-01 March 2014, Dhaka, Bangladesh.

Islam MT, MM Rashid and K Mostafa, 2008. Histopathological studies of experimentally infected shing, Heteropneustes fossilis with Aeromonas hydrophila bacteria. Prog. Agri., 19: 89-96.

IUCN Bangladesh 2000. Red book of threated fishes of Bangladesh, IUCN- The world conservation union .xii, $116 \mathrm{pp}$.

Kashem M, L Bhaduri, 1998. Identification of Flabobacteriam columnarie from diseased Anabus testudineus. Pakistan J. Bio. Sci., 11: 225-230.

Khan MN, S Islam and MG Hussain, 2003. Marginal analysis of culture of stinging catfish (Heteropneustes fossilis): Effect of different stocking density in earthen ponds. Pakistan J. Bio. Sci., 6: 666-670.

Lilley JH, RB Callinan, S Chinabut, S Kanchanakhan, IH MacRae and MJ Philips, 1998. Epizootic Ulcerative Syndrome (EUS). Technical Hand Book, The Aquatic Animal Health Research Institute, Bangkok. pp. 88.

Rahman AKA, 1989. Fresh water fishes in Bangladesh. The Zoological Society of Bangladesh, Dhaka. 4: 22-29.

Rashid M, MA Hasan, K Mostafa and MA Islam, 2008. Isolation of Aeromonas hydrophila from EUS affected shing Heteropneustes fossilis from a fish farm of Mymensingh. Prog. Agri., 19: 117-124.

Majumder K and A Bhadra, 1999. Investigation of causative agents of ulcer disease of fresh water fishes of Dhaka division. Jour. BioSi., 4: 115-119.

Majumder K and A Bhadra, 2006. Preparation of anti Aeromonas hydrophila serum in two rabbits. Inter. J. Bio. Res., 2: 25-29.

Mostafa M and F Ahamed, 2008. Pethogenesis of Aeromonas hydrophila on Heteropneustes fossilis. Bangladesh J. of Fis., 8: 38-41.

Narejo NT, MA Salam, MA Sabur and SM Rahmatullah, 2005. Effect of stocking density on growth and survival of indigenous catfish, Heteropneustes fossilis (Bloch) reared in cemented cistern fed on formulated feed. Pakistan J. Zoo., 37: 49-52.

Paul VI and TK Banerjee, 1997. Histopathological changes induced by ambient ammonia (ammonium sulphate) on the opercular linings of the catfish Heteropneustes fossilis. Dis. Aqua. Orga., 28: 151-161.

Plumb JA, 1994. Health maintenance of cultured fishes, principal microbial diseases. CRC Press Boca Raton Ann Arbor, London, Tokyo. p. 42.

Prasad MS, P Prasad, SD Peters and M Shil, 1995. Light and scanning electron microscopic studies on the effect of mercuric chloride in the catfish, Heteropneustes fossilis: Histopathology of the air breathing organs. Prog. Indian Natu. Sci. Aca. Board of Bio. Sci., 61: 363-370.

Rahman MM and MBR Chowdhury, 1996. Isolation of bacterial pathogen causing on ulcer disease in farmed carp fishes of Mymensingh. Bangladesh J. Fis., 19: 103-110.

Rahman MS, MY Chowdhury, AKMA Haqu and MS Haq, 1982. Limnological studies of four fishponds. Bangladesh J. Fis., 2: 25-35.

Roberts RJ, GN Frerichs, K Tonguthai and S Chainabut, 1994. Epizootic ulcerative syndrome of farmed and wild fishes. In: Muir, J.F. and Roberts, R.J. (eds) pp. 207-239. Recent Advances in Aquaculture V. Blackwell Science.

Sabur MA, 2006. Studies on the ecology of the pathogenic bacteria Aeromonas hydrophila in indigenous and exotic carps under polyculture condition. PhD Thesis submitted to the Department of Aquaculture, 
Bangladesh Agricultural University, Mymensingh. 163 p.

Sahoo PK and SC Mukherjee, 1997. In-vitro susceptibility of three bacterial pathogens of catfish to 23 antimicrobial agents. Indian J. Fis., 44: 393-397.

Sahoo PK, BB Sahu, J Mohanty, G Murjani and SC Mukherjee, 1998. Ulcer diseases in catfish, Heteropneustes fossilis. Proceedings of the National Symposium on Technological Advancements in Fisheries and its impact on Rural Development. 5-7 December, 1995. pp. 147-152.

Sarder H and M Khan, 1999. Haemotological parameter of Clarias batrachus. Inter. J. fis. Res., 11: 134- 139.

Srivastava ST, ND Singh, R Sinha and AK Srivastava, 1998. Malachite green induced histopathological lesions in the liver of a freshwater catfish, Heteropneustes fossilis (Bloch). J. Adv. Zoo., 19: 46-49.

Srivastava CB, 1975. Fish pathological studies in India: A brief review. Dr. B.S. Chauhan Comm. pp. 649-358.

Swaminathan TR, G Rathore, R Abidi and D Kapoor, 2004. Detection of Aeromonas hydrophila by polymerase chain reaction. Indian J. Fis., 51: 251-254. 